\title{
The Central Government Behavior Analysis in Development of Chinese New Energy Industry
}

\author{
Haoxin Dong, Hui Zhao \\ Graduate School of Chinese Academy of Social Sciences, Beijing, China \\ Email:875197443@qq.com
}

How to cite this paper: Dong, H.X. and Zhao, H. (2017) The Central Government Behavior Analysis in Development of Chinese New Energy Industry. Low Carbon Economy, 8, 41-50. https://doi.org/10.4236/lce.2017.82004

Received: April 14, 2017

Accepted: May 14, 2017

Published: May 17, 2017

Copyright $\odot 2017$ by authors and Scientific Research Publishing Inc. This work is licensed under the Creative Commons Attribution International License (CC BY 4.0).

http://creativecommons.org/licenses/by/4.0/

\section{(c) (i) Open Access}

\begin{abstract}
The purpose of this study is to show the performance of the Central Government in the new energy industry, and to analyze the effect of Central Government's new energy documents. The essay intends to sum up almost new energy policies from the Central Government. The present study counts the total number of new energy policies, analyzes the distribution frequency of the new energy policies in the national institutions, and sorts out the purpose of the implementation of those new energy policies in order to understand the focus of the Central Government. Meanwhile, using a questionnaire, this essay collects data on evaluation of the public's satisfaction with the new energy policy and the effect of the implementation of the new energy policy. So, based on a large amount of materials, the authors discuss about China how to promote the application of Central Government policies in this field are benefit to enrich the research materials of this field.
\end{abstract}

\section{Keywords}

New Energy Policy, Central Government, New Energy Industry, Effect

\section{Introduction}

Nowadays, China has become the largest energy consumer country, accounting for $22.4 \%$ of global consumption [1]. Energy composition is heavily dependent on traditional fossil fuels like coal or others. Over-reliance on coal, oil and other traditional energy could easily lead to shortage of resources, environment pollution and energy security pressure [2] [3]. As a strategic emerging industries, new energy industry has unparalleled advantages, not only it can effectively reduce air pollution, but it can also protect the environment, adjust the energy consumption structure, save resources, promote economic transformation, and change industrial growth mode. Under the background of the present era, the new energy industry represents the direction of the development of science and 
technology in the future. So, the governments all over the world are making policies to develop low-carbon economy, and promote the development of new energy industry and industrial competitiveness. In terms of the characteristics of the new energy industry itself, the new energy products have obvious environmental friendly, the earnings are not exclusive, belonging to public products. The positive externality of the industry has become a determining factor for Central Government support. At the same time, China's new energy industry has its own characteristics, due to the late start, the boundary of government interests and the boundary of power are not clear, resulting in the new energy industry in China is weak, industry overcapacity contradiction is outstanding, the structure and industrial chain development are not reasonable [4]. The Central Government has adopted a series of measures, including the development of laws and regulations and industrial development planning, financial support policy, technology research and development innovation policies, to some extent, promote the development of China's new energy industry. But there are some problems, such as overcapacity. Therefore, combing the characteristics and policy objectives of the Central Government behavior, and using the results of questionnaires to analyze the public's satisfaction with the Central Government's new energy policy are conducive to the Central Government to better promote the development of new energy industries.

\section{Literature Review}

The China government "is an important issue for developing and transition economies" [5]. The government determines the direction of economic development and industry planning, and often takes fiscal and taxation relief [6] [7] [8], technical support, safeguard fair and other means to support high-tech industry [9] [10]. China's new energy industry is still in the primary stage of development, there are many problems and development bottleneck. So the market defect forces the government to become the driving force of the development of the new energy industry. The Central Government has gradually listed the new energy industry as an important part of the economic and social strategy [11], and introduced a series of guiding policies and incentives to achieve a leap forward development.

The development of new energy industry in the whole world is also relying on the promotion of policies. The development of the new energy industry of America takes its' place in the front ranks of the world, and the policy systems are relatively perfect. The United States federal tax law on renewable energy technology R \& D has the incentive to promote the development of new energy industry [12]. Besides, the life cycle of alternative energy technologies is analyzed, the cost of private and social costs (including external costs, net tax costs and subsidies) are investigated, and achieve "Internalization of external costs" [13]. In general, the US government needs to find a suitable way to develop new energy industry, which is to focus on environmental policy or to reduce costs through market pressure [14]. Canada's new energy policy formulation doped 
more political factors, not only strengthening the government intervention, but also taking the spontaneous market formation of the fixed price purchase system [15]. Europe's policy has its own characteristics. EU countries are more participants, the development level is different, such as Turkey in the EU's new energy policy framework, Turkey needs to learn from the EU experience, reduce the approval process [16]. Therefore, the smooth implementation of the EU policy, the members of EU need to explore ways to have a sense of identity among different countries [17]. However, the previous literature did not analyze the behavior of China's Central Government in the development of new energy industry, so which makes this paper research has some theoretical and practical significance.

\section{Method}

In this paper, a combination of qualitative and quantitative methods to analyze the Central Government new energy policy and the public satisfaction with the policy.

On the one hand, in view of this paper is mainly about the Central Government new energy behavior and satisfaction analysis, so this essay mainly to take qualitative analysis method to collect and analyze the focus and main approaches of the Central Government's new energy polices. According to limitation statistics, the Central Government issued 111 documents from 1997 to 2016. Documents mainly come from the ministries websites. This essay will analyze the distribution frequency of the new energy policies in the national institutions, and sort out the purpose of the implementation of those new energy policies in order to understand the focus of the Central Government. On the other hand, in order to investigate the social public satisfaction on the Central Government new energy policy, this essay takes the form of questionnaires. The poll gave out 30 questionnaires, and the amount of effective questionnaires is 30 . The investigation object is the social public, and assigned randomly. The questionnaire is single choice, and the results of the analysis take the combination of qualitative and quantitative way. The method of quantitative analysis is analytic hierarchy process (AHP) and the Fuzzy Mathematics to evaluate the new energy policy of the Central Government and whether it has reached the degree of public satisfaction based on the results of the questionnaire.

\section{Findings}

\subsection{Focus of the Central Government New Energy Policy}

From the Central Government policy formulation and promulgation of the Department's perspective, in the 111 policy documents, at least including 17 departments, and more than one file are promulgated and implemented by ministries jointly. The National Development and Reform Commission and the National Energy

Board accounted for $23.4 \%$, followed by the Ministry of Finance to reach 15.2\%. Detailed ministries distribution are shown in Table 1. 
Table 1. The distribution of the new energy policy of the central government during 1997-2016.

\begin{tabular}{|c|c|c|c|}
\hline Number & Name & Amount & Proportion \\
\hline 1 & Development and Reform Commission & 34 & $23.40 \%$ \\
\hline 2 & National Energy Board & 34 & $23.40 \%$ \\
\hline 3 & Ministry of Finance & 22 & $15.20 \%$ \\
\hline 4 & Ministry of Industry and IT & 12 & $8.30 \%$ \\
\hline 5 & Central People' Government & 11 & $7.60 \%$ \\
\hline 6 & Ministry of Science and technology & 10 & $6.90 \%$ \\
\hline 7 & Ministry of Commerce & 5 & $3.40 \%$ \\
\hline 8 & State Administration of Taxation & 4 & $2.80 \%$ \\
\hline 9 & Ministry of Environment Protection & 2 & $1.40 \%$ \\
\hline 10 & Electricity Regulatory of Commission & 2 & $1.40 \%$ \\
\hline 11 & State Forestry Administration & 2 & $1.40 \%$ \\
\hline 12 & Ministry of Housing and Urban- Rural Development & 2 & $1.40 \%$ \\
\hline 13 & People's Congress Standing Committee & 1 & $0.70 \%$ \\
\hline 14 & Ministry of Land and Resources & 1 & $0.70 \%$ \\
\hline 15 & Ministry of Agriculture & 1 & $0.70 \%$ \\
\hline 16 & $\begin{array}{l}\text { Leading Group Office of Poverty } \\
\text { Alleviation and Development }\end{array}$ & 1 & $0.70 \%$ \\
\hline 17 & National Government Offices Administration & 1 & $0.70 \%$ \\
\hline
\end{tabular}

111 policy documents contain a wide range of nine aspects, in the four areas of photovoltaic, wind energy, biomass energy and new energy vehicles, which are used in the production of the whole industrial chain. Nine policy oriented content by large to small, and the proportion is relatively reasonable. Detailed classifications are shown in Table 2.

\subsection{The Main Approaches and Objectives of the Central Government Actions}

According to nine policies oriented of the Central Government's new energy policy, combined with sample 111 new energy policy, this essay illustrates the main actions of each policy under the guidance of the specific text, and lists the relevant policy and policy provisions. Table 3 for details.

Government policies mainly including the legal means, administrative means, financial instruments, taxation and other means, aiming at different policy for different means, and so forth.

The Central Government's new energy policy means are pretty abundant, combined with the policy guidance. They have become a complex policy system and conduction mechanism. Comprehensive consideration of the new energy industry development process, the policy promulgated departments and policy means, it will be found the policy has some distinct characteristics and clear purposes: 
Table 2. The central government's new energy policy oriented frequency statistics during 1997-2016.

\begin{tabular}{cccc}
\hline Number & Policy Orientation & Amount & Proportion \\
\hline 1 & Industry Planning & 48 & $43.60 \%$ \\
2 & Project Management & 14 & $12.70 \%$ \\
3 & Market Promotion & 14 & $12.70 \%$ \\
4 & Electricity Price Guidance & 13 & $11.80 \%$ \\
5 & Enterprise Support & 7 & $6.40 \%$ \\
6 & Technology Guidance & 5 & $4.50 \%$ \\
7 & Industry Supervision & 4 & $3.60 \%$ \\
8 & Market Access & 3 & $2.70 \%$ \\
9 & Law Guidance & 2 & $1.80 \%$ \\
\hline
\end{tabular}

Table 3. The new energy policy of the central government.

\begin{tabular}{|c|c|c|c|}
\hline Policy Orientation & Policy Approach & Typical Policy & Regulation Details \\
\hline \multirow{4}{*}{$\begin{array}{l}\text { Industry } \\
\text { Planning }\end{array}$} & $\begin{array}{l}\text { Administrative } \\
\text { Order }\end{array}$ & $\begin{array}{l}\text { Renewable energy development } \\
\text { in middle and long-term }\end{array}$ & $\begin{array}{l}\text { National wind-power total installed capacity } \\
\text { reach to 5,000,000 kilowatt in } 2010\end{array}$ \\
\hline & Financial Subsidy & $\begin{array}{l}\text { The state council opinion to promote } \\
\text { photovoltaic healthy development }\end{array}$ & $\begin{array}{l}\text { Encourage local government in all levels to } \\
\text { make matching financial subsidy } \\
\text { policy base on national standard }\end{array}$ \\
\hline & Taxation Relief & $\begin{array}{l}\text { National planning to develop } \\
\text { forestry biomass energy }\end{array}$ & $\begin{array}{l}\text { Molding fuels enjoys the policy of } \\
\text { added-value } 100 \% \text { levied immediately return }\end{array}$ \\
\hline & $\begin{array}{c}\text { Project } \\
\text { Demonstration }\end{array}$ & $\begin{array}{l}\text { Energy-saving and new energy } \\
\text { vehicles industry develop-plan }\end{array}$ & $\begin{array}{l}\text { Pratically promote new energy } \\
\text { vehicles pilot demonstration }\end{array}$ \\
\hline $\begin{array}{c}\text { Project } \\
\text { Management }\end{array}$ & $\begin{array}{l}\text { Administrative } \\
\text { Order }\end{array}$ & $\begin{array}{l}\text { Interim scheme of wind farm } \\
\text { project early work }\end{array}$ & $\begin{array}{l}\text { Wind farm project early-work implement } \\
\text { combined model of administrative hierarchical } \\
\text { management and centralized technical management }\end{array}$ \\
\hline \multirow[t]{4}{*}{$\begin{array}{c}\text { Market } \\
\text { Promotion }\end{array}$} & $\begin{array}{l}\text { Administrative } \\
\text { Order }\end{array}$ & $\begin{array}{l}\text { Implement scheme of government } \\
\text { agency or public institution to } \\
\text { purchase new energy vehicles }\end{array}$ & $\begin{array}{l}\text { New energy vehicles promote application } \\
\text { city's government agency or public institution } \\
\text { have equipment proportion no less than } \\
30 \text { percents of total in same year }\end{array}$ \\
\hline & $\begin{array}{l}\text { Financial } \\
\text { Subsidy }\end{array}$ & $\begin{array}{l}\text { Notice on conduct work of } \\
\text { energy-saving or new energy vehicle } \\
\text { demonstration promotion pilots }\end{array}$ & $\begin{array}{l}\text { Subsidy for new energy vehicles } \\
\text { meeting the requirement }\end{array}$ \\
\hline & $\begin{array}{l}\text { Taxation or } \\
\text { Cost Relief }\end{array}$ & $\begin{array}{l}\text { Notice on exempting new energy } \\
\text { vehicle purchase-tax }\end{array}$ & $\begin{array}{l}\text { Exempting new energy vehicle } \\
\text { purchase-tax during the policy-time }\end{array}$ \\
\hline & $\begin{array}{c}\text { Project } \\
\text { demonstration }\end{array}$ & $\begin{array}{l}\text { Notice on undertaking private } \\
\text { purchase new energy vehicle subsidy pilot }\end{array}$ & $\begin{array}{l}\text { Implement-scheme to choose } 5 \text { cities drawing up } \\
\text { private purchase new energy vehicle subsidy pilot }\end{array}$ \\
\hline \multirow[t]{2}{*}{$\begin{array}{l}\text { Enterprise } \\
\text { Support }\end{array}$} & $\begin{array}{l}\text { Financial } \\
\text { Subsidy }\end{array}$ & $\begin{array}{l}\text { Issued scheme on distributed photovoltaic } \\
\text { power project subsidy of Finance Ministry }\end{array}$ & $\begin{array}{l}\text { Country gives subsidy to distributed photovoltaic } \\
\text { power project according to electricity quantity }\end{array}$ \\
\hline & $\begin{array}{l}\text { Taxation } \\
\text { Relief }\end{array}$ & $\begin{array}{l}\text { Notice on photovoltaic power } \\
\text { added-value tax policy }\end{array}$ & $\begin{array}{l}\text { Conduct } 50 \% \text { added-value tax levied immediately } \\
\text { returned for tax payer sell of self-manufacture } \\
\text { electricity products using solar energy }\end{array}$ \\
\hline Law Guidance & Law Approaches & omit & omit \\
\hline Others & $\begin{array}{l}\text { Administrative } \\
\text { Order }\end{array}$ & $\begin{array}{l}\text { Notice on related issue to adjust renewable } \\
\text { energy electricity price added-standard } \\
\text { and environment-protect price }\end{array}$ & $\begin{array}{l}\text { Added standard positioning } 1.5 \text { cents per hour } \\
\text { each kilowatt impose to other renewable } \\
\text { energy electricity use except resident } \\
\text { life or agricultural production }\end{array}$ \\
\hline
\end{tabular}


First of all, the industry plannings update frequently and promoting policies keep close pace with markets. In recent years, new energy industry product structure is not balanced, excess capacity and capacity shortage both exist, inadequate infrastructure facilities, intensified corporate reshuffle process have resulted in greater pressure to survive for development of new energy enterprise in all fields, therefore the government has promoted industry planning to make industrial development goals, has increased infrastructure construction of new energy, has promoted new energy products to expand domestic demands, and these have a positive role to maintain the survival or development of emerging industries.

Secondly, policy guidance has pluralism extends and effective combination with policy approaches. Nine policy guidances, combining with five policy instruments, are helpful to reduce the time lag of new energy policy implementation and improve the effectiveness. New energy industry is a field with openness, complexity and professionalism. Openness gives the vitality of new energy industry. Cross collection of different industries have great benefits to new energy industry chain extending and kinds of production enriching. Through multi-perspectives and multi-levels policy system with implementing approaches, guaranteeing new energy policy has right targets and proper tightness in corresponding market nodes, and it guaranteed healthy developments of new energy industry in policy level.

\subsection{Results of Questionnaires}

In terms of background, the sex ratio of respondents is respectively $63.33 \%$ and $36.67 \%$, mainly ages of 20 to $30(73.33 \%)$, students and $\mathrm{PhD}$ have a relatively high percentage of the respondents, reached $66.67 \%$ and $63.33 \%$ respectively. In cognition on new energy products, about two thirds of respondents are not engaged in new energy industry, and know nothing about new energy industry. But, few respondents have bought new energy products, $80 \%$ of respondents have used those products. It is easy to understand $53.33 \%$ of respondents know something about the new energy subsidy policy. In terms of social public evaluation and satisfaction on the Central Government new energy policy, the whole is comparatively satisfied. In order to more comprehensively evaluate the public satisfaction on the Central Government new energy policy, the essay focuses on five aspect of energy security, energy-saving and emission reduction, industrial structure, economic development and energy consumption. The social comprehensive evaluation on the energy policy will be analyzed in two steps. First of all, this essay uses the Analytic Hierarchy Process (AHP) to get energy security, energy-saving and emission reduction, industrial structure, economic development, energy consumption in the proportion of new energy policy. Secondly, this essay uses the Fuzzy Mathematics Method to get the social comprehensive evaluation on new energy policy. In terms of social public evaluation of government intervention on the development and future expectations of new energy industry, $83.33 \%$ of respondents agreed with the Central Government to keep 
intervention on this field. All respondents think government intervention is helpful to improve the social cognition of new energy products, and the future development of China new energy industry is optimistic.

\subsection{Application of Fuzzy Matrix}

Using the Analytic Hierarchy Process (AHP) to determine the weight of all aspects of the new energy policy. The essay make energy security, energy-saving emission reduction, industrial structure, economic development, energy consumption the status of the weight in China's energy industry policy set to $\varpi_{1}$, $\varpi_{2}, \varpi_{3}, \varpi_{4}$ and $\varpi_{5}$. Measure weight vector of new energy policy are $\left(\varpi_{1}, \varpi_{2}, \varpi_{3}, \varpi_{4}, \varpi_{5}\right), \sum \varpi_{i}=1, \varpi_{i} \in(0,1)$. Using the analytic hierarchy process to determine the weights of the new energy policy measures are as follows:

Energy security, energy saving and emission reduction, industrial structure, economic development, five aspects of energy consumption in China's new energy policy accounted for position of relative importance ranking survey data. In the survey data, the respondents believe that the most important ranking is 1 , the least important ranking is 5, and so on. According to the importance of the original survey data to carry out the weight of the order of the two encoding. The corresponding to the 10,2 corresponding to the 7,3 corresponding to the 5 , 4 corresponding to 3,5 is 1 ; for example, the importance order of the order 1,3 , $5,4,2$ corresponding to the weight of the two encoding values are 10, 5, 1, 3, 7 . Make energy security, energy-saving emission reduction, industrial structure, economic development, energy consumption two aspects of the 5 aspects of the weight of the encoding values are added to the overall ranking. Energy security, energy-saving emission reduction, industrial structure, economic development, energy consumption two aspects of the 5 aspects of the weight of the 5 times encoding values were 560, 824, 940, 900 and 1069, indicating that the relative importance of the energy industry in order to sort the order of energy consumption, economic development, industrial structure, energy-saving emission reduction, energy security. The relative importance of the 5 aspects of energy policy is formed by the two-two comparison matrix. According to the analytic hierarchy process, the choice of the scale is $1-9$, which is the difference between the maximum and the minimum value of 9 . Get relative importance matrix, see Table 4.

Table 4. The relative importance between the new energy policy in all aspects of the two two comparison matrix.

\begin{tabular}{cccccc}
\hline & $\begin{array}{c}\text { Energy } \\
\text { Security }\end{array}$ & $\begin{array}{c}\text { Energy saving } \\
\text { Emission } \\
\text { Reduction }\end{array}$ & $\begin{array}{c}\text { Industrial } \\
\text { Structure }\end{array}$ & $\begin{array}{c}\text { Economic } \\
\text { Development }\end{array}$ & $\begin{array}{c}\text { Energy } \\
\text { Consumption }\end{array}$ \\
\hline $\begin{array}{c}\text { Energy Security } \\
\text { Energy saving }\end{array}$ & 1 & $1 / 4$ & $1 / 6$ & $1 / 5$ & $1 / 9$ \\
Emission Reduction & 4 & 1 & $1 / 2$ & $1 / 3$ & $1 / 4$ \\
Industrial Structure & 6 & 2 & 1 & $1 / 2$ & $1 / 2$ \\
Economic Development & 5 & 3 & 2 & 1 & $1 / 3$ \\
Energy Consumption & 9 & 4 & 2 & 3 & 1 \\
\hline
\end{tabular}


To determine the weight of each aspect of the new energy policy, the two-two comparison matrix of the relative importance of the various aspects of the new energy policy. Come to energy security, energy saving and emission reduction, industrial structure, economic development, energy consumption of the 5 aspects of weight vector is $A=(0.09,0.16,0.21,0.22,0.32)$.

On the basis of determining the weight of each aspect of the new energy industry, the comprehensive evaluation of the new energy policy is using the fuzzy mathematics method. The social evaluation of the new energy policy in every aspect including satisfied, comparatively satisfied, not quite satisfied and dissatisfied. According to the social assessment of the energy security of the new energy policy, $10 \%$ of the respondents said they were satisfied, $50 \%$ of the respondents said they were comparatively satisfied, $40 \%$ of the respondents said they were not quite satisfied, $0 \%$ of the respondents said they were not satisfied, thus get the evaluation of the new energy policy security satisfaction fuzzy vector is $(0.1,0.5,0.4,0)$. In the same way, it can be concluded that energy saving and emission reduction, industrial structure, economic development, and energy consumption are evaluated by fuzzy vector are $(0.07,0.53,0.37,0.03),(0.1,0.63$, $0.23,0.04),(0.1,0.67,0.23,0),(0.07,0.6,0.33,0.18)$. Get comprehensive evaluation matrix of new energy satisfaction of Central Government.

$$
R_{c}=\left(\begin{array}{cccc}
0.1 & 0.5 & 0.4 & 0 \\
0.07 & 0.53 & 0.37 & 0.03 \\
0.1 & 0.63 & 0.23 & 0.04 \\
0.1 & 0.67 & 0.23 & 0.0 \\
0.07 & 0.6 & 0.33 & 0.18
\end{array}\right)
$$

The new energy policy of the central government in all aspects of weight vector and new energy policy satisfaction evaluation matrix, and to get the new energy policy satisfaction evaluation vector:

$$
\begin{aligned}
A O R_{c} & =(0.09,0.16,0.21,0.22,0.32)\left[\begin{array}{cccc}
0.1 & 0.5 & 0.4 & 0 \\
0.07 & 0.53 & 0.37 & 0.03 \\
0.1 & 0.63 & 0.23 & 0.04 \\
0.1 & 0.67 & 0.23 & 0.0 \\
0.07 & 0.6 & 0.33 & 0.18
\end{array}\right] \\
& =(0.09,0.60,0.30,0.07)
\end{aligned}
$$

If the essay further calculate the social satisfaction of the new energy policy, we will be satisfied, comparatively satisfied, not quite satisfied and not satisfied with the value of $+4,+2,-2,-4$, then it can get the social satisfaction of the new energy policy of the central government. The evaluation value is 0.6628 . It can be concluded that the new energy policy of the central government is still comparatively satisfied.

\section{Conclusion}

The Central Government clarifies the essence of development of new energy industry in China, makes purpose of promoting new energy technology progress, 
enhances the core competitiveness of new energy enterprises and adjusting energy consumption institutions, uses method of the legal guidance, and demonstration projects and fiscal policy, and so on. Policies promulgated by the main form of the new energy policy system have played an important role for the development of new energy industry in China. But, there are some problems at the same time can be concluded from questionnaires. For example, lack of public participation awareness and lack of new energy production penetration. The social public' attitude to the Chinese Central Government intervention in general speaking is a positive. Meanwhile, the public also welcome the central government to maintain a certain degree of intervention. Therefore, the Central Government should focus on the actual development of China's new energy industry, improve the imperfections in the work in order to better promote the development of new energy industry in China. However, this paper does not make specific research on implementation of the policy, so the policy performance will be more in-depth analysis in the future.

\section{References}

[1] BP. Statistics Review of World Energy 2014 Workbook, 6.

[2] Zhang, X.H., Hu, H., Zhang, R. and Deng, S.H. (2014) Interactions between China's Economy, Energy and the Air Emissions and Their Policy Implications. Renewable and Sustainable Energy Reviews, 38, 624-638.

[3] Zheng, S.Q., Kahn, M.E., Sun, W.Z. and Luo, D.L. (2014) Incentives for China's Urban Mayors to Mitigate Pollution Externalities: The Role of the Central Government and Public Environmentalism. Regional Science and Urban Economics, 47, 61-71.

[4] Wang, B. (2012) Study on Effects of Local Government Behavior to New Energy Industry. Dongbei University of Finance \& Economics, Dalian, 46-59.

[5] Jin, H.H., Qian, Y.Y. and Weingast, B.R. (2005) Regional Decentralization and Fiscal Incentives: Federalism, Chinese Style. Journal of Public Economics, 89, 17191742 .

[6] Xia, B. and Li, Y. (2012) Analysis on the Impact of Tax Policy over China's New Energy Industry Development. Physics Procedia, 25, 1277-1284.

[7] Han, L. and Kung, J.K. (2015) Fiscal Incentives and Policy Choices of Local Governments: Evidence from China. Journal of Development Economics, 116, 89-104.

[8] Shao, Y.Y., Redrigo, H. and Liu, P. (2015) Government Intervention and Corporate Policies: Evidence from China. Journal of Business Research, 68, 1205-1215.

[9] Gao, P. (2015) Government in the Catching-Up of Technology Innovation: Case of Administrative Intervention in China. Technological Forecasting \& Social Change, 96, 4-14.

[10] Guan, J.C. and Yam, R.C.M. (2015) Effects of Government Financial Incentives on Firms' Innovation Performance in China: Evidences from Beijing in the 1990s. Research Policy, 44, 273-282.

[11] Li, X.N. and Li, Y.F. (2011) Diving Forces on China's Circular Economy: Form Government's Perspectives. Energy Procedia, 5, 297-301.

[12] Hill, L.J. and Hadley, S.W. (1995) Federal Tax Effects on the Financial Attractiveness of Renewable versus Conventional Power Plants. Energy Policy, 23, 593-597.

[13] Owen, A.D. (2004) Environmental Externalities, Market Distortions and the Economics of Renewable Energy Technologies. The Energy Journal, 25, 127-156.

[14] Finon, D. and Perez, Y. (2007) The Social Efficiency of Instruments of Promotion of Renewable Energies: A Transaction-Cost Perspective. Ecological Economics, 
62, 77- 92.

[15] Stokes, L.C. (2013) The Politics of Renewable Energy Policies: The Case of Feed-In Tariffs in Ontario, Canada. Energy Policy, 56, 490-500.

[16] Sirin, S.M. and Ege, A. (2012) Overcoming Problems in Turkey's Renewable Energy Policy: How Can UN Countries? Renewable and Sustainable Energy Reviews, 16, 4917-4926.

[17] Bohne, E. (2011) Conflicts between Regulatory Cultures and UN Energy Regulations. Utilities Policy, 19, 255-269.

Submit or recommend next manuscript to SCIRP and we will provide best service for you:

Accepting pre-submission inquiries through Email, Facebook, LinkedIn, Twitter, etc. A wide selection of journals (inclusive of 9 subjects, more than 200 journals)

Providing 24-hour high-quality service

User-friendly online submission system

Fair and swift peer-review system

Efficient typesetting and proofreading procedure

Display of the result of downloads and visits, as well as the number of cited articles

Maximum dissemination of your research work

Submit your manuscript at: http://papersubmission.scirp.org/

Or contact lce@scirp.org 